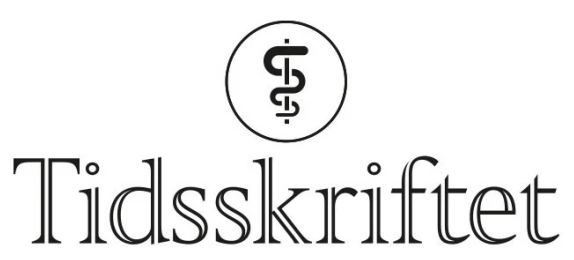

DEN NORSKE LEGEFORENING

\title{
Fokus på kvalitet i medisinsk obduksjonspraksis
}

KOMMENTAR

\section{STINE KRISTOFFERSEN}

stine.kristoffersen@helse-bergen.no

Stine Kristoffersen er seksjonsoverlege ved Avdeling for patologi, Haukeland universitetssjukehus.

HEIDI GRøNSETH

ANNA KRISTINE MYRMEL SALE

KARIN COLLETT

MARIA THORSTEINSDOTTIR

Ingen av forfatterne har oppgitt noen interessekonflikter.

Tusen takk til forfatterne av artikkelen «Kvaliteten på norske sykehusobduksjoner», publisert i Tidsskriftet den 20.08.21(1)! Det er en viktig problemstilling som adresseres, men hovedtrekkene i artikkelen er nedslående lesning - lange svartider og feil i obduksjonsrapporter som får konsekvenser for Dødsårsaksstatistikken. Konklusjonene er utelukkende basert på materiale fra 2014, men det blir likevel poengtert at det ikke er "grunn til å tro at det har skjedd endringer i medisinsk obduksjonspraksis i Norge» etter 2014.

Sannheten er at mye har endret seg siden 2014, og vi som er obduksjonspatologer ved Haukeland universitetssykehus kjenner oss i liten grad igjen i beskrivelsene i artikkelen. På bakgrunn av dette $\emptyset$ nsker vi å belyse noen aspekter ved nåtiden.

Seksjon for autopsi ved Haukeland universitetssykehus er nå den største av sitt slag i Norge, med 189 voksenobduksjoner og 63 fosterobduksjoner i 2020 (tall fra Den norske patologforening). Fokus på kvalitet gjenspeiles i at vi i som første (og så langt eneste) patologiavdeling i Norge har vært akkreditert for obduksjonsvirksomheten siden 2019.

De siste årene har Seksjon for autopsi gjort flere endringer med formål å bedre kvaliteten på medisinske obduksjoner. I 2019 ble en egen faggruppe for autopsi, etablert. Denne er sammensatt av fem dedikerte overleger med spesiell kompetanse og interesse for 
obduksjonspatologi, og som også deltar i diagnostikk innenfor andre faggrupper. Obduksjonsfaggruppen har dessuten ansvar for hjerte- og karpatologi. Gruppen har regelmessige møter, hvor vanskelige kasus, vanlige problemstillinger og interessante funn blir diskutert. Klinikere som har behandlet pasientene blir invitert til demonstrasjon av makroskopiske funn når dette er mulig - noe det stort sett er. Vi setter stor pris på disse møtene, som gir mulighet for gode tverrfaglige diskusjoner, og som danner grunnlag for felles forståelse av ulike sykdomsforløp.

Svartider er et stadig diskutert tema, da vi vet at både behandlende leger og pårørende ofte venter på den endelige rapporten. Vi har satt oss mål om å besvare $95 \%$ av rapportene innen 6o kalenderdager, et mål som ikke er fullstendig oppnådd per dags dato, men det betyr ikke at vi har resignert. Dette er noe vi trenger og ønsker å ha fokus på.

Vi ønsker å ha en obduksjonsvirksomhet som våre kliniske kolleger og befolkningen har høy tillit til. Skulle man ta hovedtrekkene i artikkelen inn over seg, kunne man få inntrykk av at det har lite for seg å rekvirere en medisinsk obduksjon. Til alle våre kjære kliniske kolleger! Obduksjonspatologi er et viktig fagfelt som tilstreber å følge den kliniske utviklingen. Vi jobber kontinuerlig med å holde høy kvalitet på våre obduksjonsrapporter, og dere skal føle dere trygge på at vi tar oppgaven vår på det største alvor, hver gang dere rekvirerer en obduksjon fra Seksjon for autopsi, Haukeland universitetssykehus.

\section{LITTERATUR}

1. Eng HM, Bie RB, Skjulsvik AJ et al. Kvaliteten på medisinske obduksjonsrapporter. Tidsskr Nor Legeforen 2021; 141. doi: 10.4045/tidsskr.20.10oo. [PubMed][CrossRef]

Publisert: 13. desember 2021. Tidsskr Nor Legeforen. DOI: 10.4045/tidsskr.21.0814

(C) Tidsskrift for Den norske legeforening 2023. Lastet ned fra tidsskriftet.no 26. april 2023. 